\title{
The Influence of Current Ratio, Quick Ratio and Net Profit Margin on Return on Assets at PT. Hero Supermarket Tbk
}

\author{
Muliahadi Tumanggor \\ Universitas Pamulang \\ E-mail: Dosen00871@unpam.ac.id
}

(Received: January-2020; Reviewed: February-2020; Accepted: March-2020;

Avalaibel Online: March-2020; Published: March-2020)

This is an open access article distributed under the Creative Commons Attribution License CC-BY-NC-4.0 C2020 by author (https://creativecommons.org/licenses/by-nc/4.0/)

\begin{abstract}
The role of finance in a company is very important and is needed both in large and small companies, both private and state-owned companies. This study aims to determine the effect of the current ratio, quick ratio and net profit margin on return on assets at PT. Hero Supermarket Tbk 2014-2018 period. The method used is explanatory research with a sample of as many financial statements. The analysis technique uses statistical analysis with regression testing, correlation, determination, and hypothesis testing. The results of this study the current ratio does not significantly influence the return on assets of $1.5 \%$, the hypothesis test obtained significance $0.817>0.05$. The quick ratio does not significantly influence the return on assets of $30.3 \%$, the hypothesis test obtained significance of $0.258>0.05$. Net profit margin has a significant effect on the Return on assets of $97.6 \%$, the hypothesis test obtained a significance of $0,000<0.05$. The current ratio, quick ratio, and net profit margin simultaneously have a significant effect on the Return on assets of $99.8 \%$, the hypothesis test obtained significance of 0.003 $<0.05$.
\end{abstract}

Keywords: Current ratio, quick ratio, net profit margin, Return on Asset.

\section{INTRODUCTION}

Seeing the development of an increasingly advanced business world, many large or small scale companies, have a great concern in the financial sector (Fahmi, 2014; Harahap, 2009; Raharjaputra, Hendra, 2011; Sudana, 2011). This causes intense competition between one company with another company to get maximum profit. Increasing competition resulted in companies suddenly experiencing setbacks. Therefore, in order for a company to grow and develop, the company must pay more attention to the condition and performance of the company.

Company management must be able to manage everything that can affect the entire process in the company (Assauri, 2008; Hanafi, 2008; Rusdiana \& Zaqiah, 2014; Sedarmayanti, 2017). If this can be implemented, then achieving company goals will be easier to achieve. The 
calculation of the costs incurred correctly is very useful, so the company is expected to compete competitively with competitor companies that produce similar products or services.

The role of finance in a company is very important and is needed both in large and small companies, both private and state-owned companies (Halim, 2012; Rudianto, 2013). Especially when it comes to financial matters which are an important part of a company. Media that can be used to assess company performance is financial statements. Financial statements are the final results of the recording and calculation process that contains a summary of financial transactions during a certain period. Management delegates the task of recording these financial statements to an accountant. In order to clearly describe the purpose of the report to be submitted, the financial statements are prepared based on the standard (Bastian, 2019; Raharjaputra, Hendra, 2011; Setijaningsih, 2012; Tjhen, Saleh, \& Stinjak, 2012).

At first the financial statements for a company only a test tool from the work of bookkeeping. Furthermore, financial statements are not only a testing tool but also as a basis for determining or assessing the financial position of the company concerned by conducting an analysis of financial performance. Through the results of the analysis, it can be seen the use of economic resources, the obligations that must be met and the capital owned by the company, as well as the results achieved by the company. (Budi Rahardjo, 2009; Fahmi., 2011; Umboh et al., 2013; Yolanda \& Kesuma, 2014). The importance of financial statements as information in assessing company performance is a requirement that financial statements must reflect the actual state of the company at a certain time period. One form of accounting information to determine the assessment of the company's financial performance can be done by conducting an analysis using financial ratios for certain periods of time based on the company's financial statements (Charter \& Milton F, 2006; Hery, 2019; Mardiasmo, 2002; Mulyadi, 2014; Romney, 2013).

Financial Ratios are a company's financial analysis tool to assess the performance of a company based on the comparison of financial data contained in the financial statement items (balance sheet, profit/loss statement, cash flow statement). The ratio describes a relationship or balance between a certain amount with another amount (Edy Susanto, 2019; Faisol, 2007; Mandasari, 2015; Pranomo, 2014). A financial analysis will give a good result if in its use there is a collection to show a change in the financial condition or operational performance in a certain period. Furthermore, it can provide an overview of capital and patterns of change that can ultimately provide an indication of the risks and business opportunities that it develops. Ratio analysis can provide an assessment of a report on a company that is used as a material consideration for investors and creditors for decision-making material or consideration of the company's achievements and future prospects. Ratio analysis uses existing reports as a basis for research.

\section{METHOD}

The type of research used is associative, where the aim is to find out the relationship between variables. The population in this study is the financial statements of PT. Hero Supermarket Tbk 2014-2018 period. The sampling technique in this study is saturated sampling, where all members of the population are sampled. Thus the sample in this study is 6 years of financial statements. In analyzing the data used the instrument test, classical assumption test, regression, coefficient of determination and hypothesis testing. 


\section{RESULT AND DISCUSSION}

Current Assets conditions, current liabilities, net income, total assets and sales at PT. Hero Supermarket Tbk period 2014-2018 experienced fluctuating developments with different levels of achievement.

\section{Descriptive Analysis}

This test used to determine the highest minimum and maximum scores, ratting scores and standard deviations of each variable. The results are as follows:

Table 1.

Descriptive Statistics Analysis Results

Descriptive Statistics

\begin{tabular}{lr|r|r|r|r}
\hline & N & \multicolumn{1}{|c}{ Minimum } & Maximum & \multicolumn{1}{c}{ Mean } & Std. Deviation \\
\hline Current Ratio (X1) & 6 & 68 & 163 & 123.33 & 31.742 \\
\hline Quick Ratio (X2) & 6 & 22 & 81 & 45.23 & 19.712 \\
\hline Net Profit Margin (X3) & 6 & 0 & 6 & 2.03 & 1.965 \\
\hline Return on Asset (Y) & 6 & 1 & 9 & 3.50 & 3.082 \\
\hline Valid N (listwise) & 6 & & & & \\
\hline
\end{tabular}

The current ratio is obtained a minimum percentage of $68 \%$ and a maximum percentage of 163 \$ with an average of $123.33 \%$ with a standard deviation of $31.742 \%$. The Quick ratio obtained a minimum percentage of $22 \%$ and a maximum percentage of $81 \%$ with an average of $45.23 \%$ with a standard deviation of $19.712 \%$. The net profit margin obtained a minimum percentage of $0.32 \%$ and a maximum percentage of $6 \%$ with an average of $2.03 \%$ with a standard deviation of $1.965 \%$. Return on assets obtained a minimum percentage of $1.46 \%$ and a maximum percentage of $9 \%$ with an average of $3.50 \%$ with a standard deviation of $3.082 \%$.

\section{Multiple Regression Analysis}

This regression test is intended to determine changes in the dependent variable if the independent variable changes. The test results are as follows:

Table 2.

Multiple Regression Testing Results

\begin{tabular}{|c|c|c|c|c|c|}
\hline \multirow[b]{3}{*}{ Model } & \multicolumn{2}{|c|}{ Coefficients $^{\mathrm{a}}$} & \multirow{3}{*}{$\begin{array}{c}\text { Standardized } \\
\text { Coefficients } \\
\text { Beta }\end{array}$} & \multirow[b]{3}{*}{$\mathrm{t}$} & \multirow[b]{3}{*}{ Sig. } \\
\hline & \multicolumn{2}{|c|}{$\begin{array}{c}\text { Unstandardized } \\
\text { Coefficients }\end{array}$} & & & \\
\hline & $\mathrm{B}$ & Std. Error & & & \\
\hline $\begin{array}{ll}1 & \text { (Constant) }\end{array}$ & 1.138 & .738 & & 1.542 & .263 \\
\hline Current Ratio (X1) & .004 & .014 & .043 & .303 & .791 \\
\hline Quick Ratio (X2) & -.040 & .029 & -.257 & -1.377 & .302 \\
\hline Net Profit Margin (X3) & 1.800 & .146 & 1.148 & 12.342 & .007 \\
\hline
\end{tabular}

a. Dependent Variable: Return on Asset (Y)

Based on the test results in the above table, the regression equation $\mathrm{Y}=1,138+0,004 \mathrm{X} 1$ $0,040 \mathrm{X} 2+1,800 \mathrm{X} 3$ is obtained. A constant of 1.138 means that if there is no current ratio and 
quick ratio, then there is a Return on the asset value of 1.138 points. Current ratio regression coefficient of 0.004 , this number is positive, meaning that every time there is an increase in the current ratio of 0.004 , the Return on assets will also increase by 0.004 points. Quick ratio regression coefficient of -0.040 , this number is positive meaning that every time there is an increase in the quick ratio of -0.040 then the Return on assets will also increase by -0.040 points. The regression coefficient of net profit margin is 1,800 , this number is positive, meaning that every time there is an increase in the net profit margin of 1,800, the Return on assets will also increase by 1,800 points.

\section{Correlation Coefficient Analysis}

Correlation coefficient analysis is intended to determine the degree of relationship strength of the independent variables on the dependent variable either partially or simultaneously. The test results are as follows:

Table 3.

Test Results Correlation Coefficient Current ratio Against Return on assets.

Correlations $^{\text {a }}$

\begin{tabular}{ll|r|r}
\hline & & $\begin{array}{c}\text { Current Ratio } \\
\text { (X1) }\end{array}$ & Return on Asset (Y) \\
\hline Current Ratio (X1) & Pearson Correlation & 1 & .123 \\
& & & .817 \\
\cline { 2 - 4 } & Sig. (2-tailed) & .123 & 1 \\
\hline Return on Asset (Y) & Pearson Correlation & & .817 \\
\cline { 2 - 4 } & Sig. (2-tailed) & & \\
\hline
\end{tabular}

a. Listwise $\mathrm{N}=6$

Based on the test results obtained by the correlation value of 0.123 means that the current ratio has a very weak relationship to Return on assets.

Table 4.

Test Results for Quick Ratio Correlation Coefficient Against Return on Assets.

Correlations $^{\mathrm{a}}$

\begin{tabular}{llr|r}
\hline & & & \\
& & Quick Ratio (X2) & Return on Asset (Y) \\
\hline Quick Ratio (X2) & Pearson Correlation & 1 & .550 \\
\cline { 2 - 4 } & Sig. (2-tailed) & & .258 \\
\hline Return on Asset (Y) & Pearson Correlation & .550 & 1 \\
\cline { 2 - 4 } & Sig. (2-tailed) & .258 & \\
\hline
\end{tabular}

a. Listwise $\mathrm{N}=6$

Based on the test results obtained by a correlation value of 0.550 means that the quick ratio has a moderate relationship to Return on assets. 
Table 5.

Test Results of the Net Profit Margin Correlation Coefficient Against Return on Assets Correlations $^{\mathbf{b}}$

\begin{tabular}{llr|r}
\hline & & \multicolumn{1}{c}{$\begin{array}{c}\text { Net Profit } \\
\text { Margin (X3) }\end{array}$} & Return on Asset (Y) \\
\hline Net Profit Margin (X3) & Pearson Correlation & 1 & $.988^{* *}$ \\
\cline { 2 - 4 } & Sig. (2-tailed) & $.988^{* *}$ & .000 \\
\hline Return on Asset (Y) & Pearson Correlation & .000 & 1 \\
\cline { 2 - 4 } & Sig. (2-tailed) & & \\
\hline \multirow{2}{*}{$\begin{array}{l}\text { **. Correlation is significant at the 0.01 level (2-tailed). } \\
\text { b. Listwise N=6 }\end{array}$} & & &
\end{tabular}

Based on the test results obtained by a correlation value of 0.988 means that the account has a very strong relationship to Return on assets.

Table 6.

Test Results Correlation Coefficient Current ratio, Net Profit Margin and Quick Ratio Simultaneously on Return on Assets.

Model Summary

\begin{tabular}{l|c|c|cr}
\hline Model & \multicolumn{2}{c}{ Model Summary } \\
\hline 1 & R Square & $\begin{array}{c}\text { Adjusted R } \\
\text { Square }\end{array}$ & $\begin{array}{c}\text { Std. Error of the } \\
\text { Estimate }\end{array}$ \\
\hline a. Predictors: (Constant), Net Profit Margin (X3) Current Ratio (X1), Quick Ratio (X2)
\end{tabular}

a. Predictors: (Constant), Net Profit Margin (X3), Current Ratio (X1), Quick Ratio (X2)

Based on the test results obtained by the correlation value of 0.999 means that the current ratio, quick ratio, and net profit margin simultaneously have a very strong relationship to Return on assets.

\section{Analysis of the Coefficient of Determination}

Analysis of the coefficient of determination is intended to determine the percentage of influence of the independent variable on the dependent variable either partially or simultaneously. The test results are as follows:

Table 7.

Test Results Determination Coefficient Current ratio of Return on Assets.

Model Summary

\begin{tabular}{|c|c|c|c|c|}
\hline Model & $\mathrm{R}$ & R Square & $\begin{array}{c}\text { Adjusted R } \\
\text { Square }\end{array}$ & $\begin{array}{l}\text { Std. Error of the } \\
\text { Estimate }\end{array}$ \\
\hline 1 & $.123^{\mathrm{a}}$ & .015 & -.231 & 3.420 \\
\hline
\end{tabular}

a. Predictors: (Constant), Current Ratio (X1)

Based on the test results obtained a determination value of 0.015 means that the current ratio has an effective contribution of $1.5 \%$ on Return on assets. 
Table 8

Test Results for the Quick Ratio Determination Coefficient on Return on Assets.

Model Summary

\begin{tabular}{|c|c|c|c|c|}
\hline Model & $\mathrm{R}$ & R Square & $\begin{array}{l}\text { Adjusted R } \\
\text { Square }\end{array}$ & $\begin{array}{l}\text { Std. Error of the } \\
\text { Estimate }\end{array}$ \\
\hline 1 & $.550^{\mathrm{a}}$ & .303 & .128 & 2.877 \\
\hline
\end{tabular}

a. Predictors: (Constant), Quick Ratio (X2)

Based on the test results obtained a determination value of 0.303 means that the quick ratio has an influence contribution of $30.3 \%$ on Return on assets.

Table 9

Test Results Determination Coefficient Net Profit Margin on Return on Assets.

Model Summary

\begin{tabular}{|c|c|c|c|c|}
\hline Model & $\mathrm{R}$ & R Square & $\begin{array}{c}\text { Adjusted R } \\
\text { Square }\end{array}$ & $\begin{array}{l}\text { Std. Error of the } \\
\text { Estimate }\end{array}$ \\
\hline 1 & $.988^{\mathrm{a}}$ & .976 & .970 & .537 \\
\hline
\end{tabular}

a. Predictors: (Constant), Net Profit Margin (X3)

Based on the test results obtained a determination value of 0.976 means that net profit margin has an influence contribution of $97.6 \%$ on Return on assets.

Table 10

Test Results Determination Coefficient Current Ratio, Quick ratio and Net Profit Margin on Return on Assets.

Model Summary

\begin{tabular}{lrr|rr|r}
\hline Model & R & R Square & \multicolumn{2}{c|}{$\begin{array}{c}\text { Adjusted R } \\
\text { Square }\end{array}$} & $\begin{array}{c}\text { Std. Error of the } \\
\text { Estimate }\end{array}$ \\
\hline 1 & $.999^{\mathrm{a}}$ & .998 & .996 & .206 \\
\hline
\end{tabular}

a. Predictors: (Constant), Net Profit Margin (X3), Current Ratio (X1), Quick Ratio (X2)

Based on the test results obtained a determination value of 0.998 means that the current ratio, quick ratio, and net profit margin simultaneously have an influence contribution of $99.8 \%$ on Return on assets, while the remaining $2.0 \%$ is influenced by other factors.

\section{Hypotesis Testing}

Hypothesis testing with a t-test is used to find out which partial hypotheses are accepted. Table 11.

Hypothesis Test Results from Current ratio of Return on Assets.

\begin{tabular}{|c|c|c|c|c|c|c|}
\hline \multicolumn{7}{|c|}{ Coefficients $^{\mathbf{a}}$} \\
\hline & \multirow[t]{2}{*}{ Model } & \multicolumn{2}{|c|}{$\begin{array}{c}\text { Unstandardized } \\
\text { Coefficients }\end{array}$} & \multirow{2}{*}{$\begin{array}{c}\text { Standardized } \\
\text { Coefficients } \\
\text { Beta }\end{array}$} & \multirow[t]{2}{*}{$\mathrm{t}$} & \multirow[t]{2}{*}{ Sig. } \\
\hline & & B & Std. Error & & & \\
\hline \multirow[t]{2}{*}{1} & (Constant) & 2.025 & 6.104 & & .332 & .757 \\
\hline & Current Ratio (X1) & .012 & .048 & .123 & .247 & .817 \\
\hline
\end{tabular}

a. Dependent Variable: Return on Asset (Y) 
Based on the test results in the table 11 , the value of $t_{\text {count }}<t_{\text {table }}$ or $(0.247<2.132)$ is obtained, thus there is no significant effect between the current ratio on Return on assets.

Table 12.

Quick Ratio Hypothesis Test Results for Return on Assets.

Coefficients $^{\mathrm{a}}$

\begin{tabular}{|c|c|c|c|c|c|c|}
\hline \multirow{2}{*}{\multicolumn{2}{|c|}{ Model }} & \multicolumn{2}{|c|}{$\begin{array}{c}\text { Unstandardized } \\
\text { Coefficients }\end{array}$} & \multirow{2}{*}{$\begin{array}{c}\text { Standardized } \\
\text { Coefficients } \\
\text { Beta }\end{array}$} & \multirow[b]{2}{*}{$\mathrm{t}$} & \multirow[b]{2}{*}{ Sig. } \\
\hline & & $\mathrm{B}$ & Std. Error & & & \\
\hline 1 & (Constant) & -.397 & 3.178 & & -.125 & .907 \\
\hline & Quick Ratio (X2) & .086 & .065 & .550 & 1.318 & .258 \\
\hline
\end{tabular}

a. Dependent Variable: Return on Asset (Y)

Based on the test results in the above table, the value of $t_{\text {count }}<t_{\text {table }}$ or $(1.318<2.132)$ is obtained, thus there is no significant effect between the quick ratio of Return on assets.

Table 13

Hypothesis Test Results From Net Profit Margin on Return on Assets.

Coefficients $^{\mathbf{a}}$

\begin{tabular}{|c|c|c|c|c|c|}
\hline \multirow[b]{2}{*}{ Model } & \multicolumn{2}{|c|}{$\begin{array}{c}\text { Unstandardized } \\
\text { Coefficients }\end{array}$} & \multirow{2}{*}{$\begin{array}{c}\text { Standardized } \\
\text { Coefficients } \\
\text { Beta } \\
\end{array}$} & \multirow[b]{2}{*}{$\mathrm{t}$} & \multirow[b]{2}{*}{ Sig. } \\
\hline & $\mathrm{B}$ & Std. Error & & & \\
\hline (Constant) & .353 & .331 & & 1.067 & .346 \\
\hline Net Profit Margin (X3) & 1.549 & .122 & .988 & 12.676 & .000 \\
\hline
\end{tabular}

a. Dependent Variable: Return on Asset (Y)

Based on the test results in the above table, the value of $t_{\text {count }}>t_{\text {table }}$ or $(12,676>2,132)$ is obtained, thus there is a significant effect of net profit margin on Return on assets.

Hypothesis testing with the F test is used to find out which simultaneous hypotheses are accepted.

Table 14.

Hypothesis Test Results from Current Ratio, Quick Ratio and Net Profit Margin on Return on Assets.

ANOVA $^{\mathrm{a}}$

\begin{tabular}{llr|r|r|r|r}
\hline Model & & Sum of Squares & \multicolumn{1}{c}{ df } & Mean Square & F & \multicolumn{1}{c}{ Sig. } \\
\hline 1 & Regression & 47.413 & 3 & 15.804 & 370.869 & $.003^{\mathrm{b}}$ \\
& & & & & & \\
\cline { 2 - 7 } & Residual & .085 & 2 & .043 & & \\
\cline { 2 - 7 } & Total & 47.499 & 5 & & & \\
\hline
\end{tabular}

a. Dependent Variable: Return on Asset (Y)

b. Predictors: (Constant), Net Profit Margin (X3), Current Ratio (X1), Quick Ratio (X2)

Based on the test results in the above table, the calculated $F_{\text {count }}>F_{\text {table }}$ or $(370,869>9,120)$, thus the fourth hypothesis proposed that there is a significant influence between the current ratio, quick ratio and net profit margin on Return on assets is accepted. 


\section{CONCLUSION}

The current ratio does not have a significant effect on the return on assets with a contribution of $1.5 \%$. Hypothesis testing obtained $\mathrm{t}_{\text {count }}<\mathrm{t}_{\text {table }}$ or $(0.247<2.132)$. The quick ratio does not have a significant effect on the return on assets with a contribution of $30.3 \%$. Hypothesis testing obtained $t_{\text {count }}>t_{\text {table }}$ or $(1.318>2.132)$. The net profit margin has a significant effect on the return on assets with an influence contribution of $97.6 \%$. Hypothesis testing obtained $t_{\text {count }}>t_{\text {table }}$ or $(12,676>2,132)$. The current ratio, quick ratio, and net profit margin have a significant effect on return on assets with a contribution of $99.8 \%$ while the remaining $2.0 \%$ is influenced by other factors. Hypothesis testing obtained by calculating the $F_{\text {count }}>F_{\text {table }}$ or $(370,869>9,120)$.

\section{REFERENCES}

Assauri, S. (2008). Manajemen Produksi dan Operasi. Jakarta: Lembaga Penerbit Fakultas Ekonomi Universitas Indonesia.

Bastian, I. (2019). Lingkup Akuntansi Sektor Publik. In Lingkup Akuntansi Sektor Publik.

Budi Rahardjo. (2009). Laporan Keuangan Perusahaan. Budi Rahardjo.

Charter, W., \& Milton F, U. (2006). Akuntansi Biaya. Salemba Empat.

Edy Susanto, M. (2019). Analisis Rasio Keuangan. Journal of Chemical Information and Modeling. https://doi.org/10.1017/CBO9781107415324.004

Fahmi. (2011). Analisis Laporan Keuangan. Edisi ke-10. Lampulo: Alfabeta.

Fahmi, I. (2014). Manajemen Keuangan Perusahaan dan Pasar Modal. Manajemen Keuangan Perusahaan dan Pasar Modal.

Faisol, A. (2007). Analisis Kinerja Keuangan Bank Pada Pt Bank Muamalat Indonesia Tbk. Bisnis dan Manajemen.

Halim, A. (2012). Akuntansi Sektor Publik Akuntansi Keuangan Daerah. In Salemba Empat. https://doi.org/ISBN: 978-979-061-226-6

Hanafi, M. (2008). Konsep Dasar dan Perkembangan Teori Manajemen. Managemen.

Harahap, S. S. (2009). Analisa Kritis Laporan Keuangan. In Teori Akuntansi. https://doi.org/www.rajagrafindo.com

Hery. (2019). Akuntansi Dasar 1 dan 2. Fundamental Management Journal.

Mandasari, J. (2015). Analisis Kinerja Keuangan dengan Pendekatan Metode RGEC pada Bank BUMN Periode 2012-2013. Jurnal Administrasi Bisnis.

Mardiasmo. (2002). Akuntansi Sektor Publik.

Mulyadi. (2014). Sistem Akuntansi Edisi 4. In salemba empat.

Pranomo, J. (2014). Analisis Rasio Keuangan Untuk Menilai Kinerja Keuangan Pemerintah Daerah (Studi Kasus Pada Pemerintah Kota Surakarta).(Joko Pramono). Jurnal Ilmiah Among Makarti.

Raharjaputra, Hendra, S. (2011). Manajemen Keuangan dan Akuntansi. In laporan keuangan merupakan alat yang sangat penting untuk memperoleh informasi sehubungan dengan 
posisi keuangan dan hasil yang telah dicapai oleh perusahaan yang bersangkutan.

Romney. (2013). Sistem Akuntansi. Sistem Akuntansi.

Rudianto. (2013). Akuntansi Manajemen Informasi untuk Pengmbilan Keputusan Strategis. In Akuntansi Manajemen.

Rusdiana, A., \& Zaqiah, Q. Y. (2014). Manajemen Perkantoran Modern. In Insan Komunika.

Sedarmayanti. (2017). Manajemen Sumber Daya Manusia. In Manajemen Sumber Daya Manusia.

Setijaningsih, H. T. (2012). Teori Akuntansi Positif dan Konsekuensi Ekonomi. Jurnal Akuntansi.

Sudana, I. M. (2011). Manajemen Keuangan Perusahaan Teori \& Praktik. In Erlangga. https://doi.org/10.1145/2505515.2507827

Tjhen, F. T., Saleh, M. H., \& Stinjak, T. J. (2012). Akuntansi Manajemen. Akuntansi Manajemen.

Umboh, D. J., Mangantar, M., Saerang, I. S., Sam, U., Manado, R., Supit, Y., ... Afandi, D. (2013). Analisis Laporan Keuangan. Journal of Chemical Information and Modeling. https://doi.org/10.1017/CBO9781107415324.004

Yolanda, R., \& Kesuma, F. (2014). Analisis Laporan Keuangan Sebagai Dasar Dalam Penilaian Kinerja Keuangan Pt. Budi Satria Wahana Motor. JURNAL Akuntansi \& Keuangan. 
146 | Pinisi Discretion Review

Volume 3, Issue 2, March, 2020 Page. 137- 146 